\title{
Multicentric glioblastoma arising in two unusual sites: cerebellum and thalamus
}

\author{
Glioblastoma multicêntrico originado em dois locais incomuns: cerebelo e tálamo
}

Eduardo Cambruzzi1'; Karla Lais Pêgas²; Mariana Fernandez Simão³; Guilherme Stüker ${ }^{3}$

\begin{abstract}
Multicentric glioblastomas (MGBM) arising in infra/supratentorial regions are uncommon lesions. The authors report a case of MGBM in a 61 year-old female patient, who presented a sudden onset of left hemiplegia. The magnetic resonance imaging (MRI) showed two expansive large lesions affecting cerebellum and thalamus, with strong contrast enhancement. The patient underwent resection of the cerebellar lesion. Microscopy revealed a high grade glial neoplasm exhibiting high mitotic index, areas of necrosis and microvascular proliferation. The neoplastic cells showed positive immunoexpression for glial fibrillary acidic protein (GFAP). The morphological findings were consistent with glioblastoma (GBM). The patient was referred to radiotherapy, with discrete signs of tumor regression after a 60-day clinical follow-up.
\end{abstract}

Key words: glioblastoma; central nervous system neoplasms; pathology; brain neoplasms; cerebellum; thalamus.

\section{INTRODUCTION}

Glioblastomas (GBM) are themostfrequent primarybrain tumors, accounting for approximately 12\%-15\% of all intracranial neoplasms and $60 \%-75 \%$ of astrocytic tumors ${ }^{(8,10,14)}$. The process affects mainly adults with a peak incidence within 45 and 75 years of age. Most GBM de novo manifest rapidly (primary), without recognizable precursor lesions, and most often occur in the subcortical white matter of the cerebral hemispheres $^{(8,10,12,14,19)}$.

GBM is an enlarging, anaplastic tumor whose clinical signs progress rapidly. Furthermore, it shows ring enhancement on postcontrast computed tomography (CT) and magnetic resonance imaging (MRI) scans. The tumor has a poor prognosis, with a mean survival rate of less than one year ${ }^{(6,7,11,16)}$. The most frequently affected sites are the temporal (31\%) and parietal lobes (24\%). GBM arising in the thalamus, brain stem, cerebellum and spinal cord are rare, inasmuch as these are uncommon sites for this neoplasm $^{(6,7,11,16,17)}$.

Herein, the authors describe a rare case of a female patient with multicentric glioblastoma (MGBM) arising in the cerebellum and thalamus and review some similar cases found in the literature.

\section{CASE REPORT}

A 61 year-old female patient was admitted at the emergency service presenting a sudden onset of left hemiplegia. On physical examination, the other organs and systems did not show any changes, as there was no previous history of relevant disease. The CT/MRI evinced two expansive large lesions affecting the thalamus and cerebellar hemisphere, to the right, with strong contrast uptake (Figure 1). An increased cerebrospinal fluid pressure on lumbar puncture was identified, and cytological examination of cerebrospinal fluid showed no presence of atypical or malignant cells. The CT/MRI scans imaging of the chest and abdomen revealed no alterations. The patient underwent resection of the cerebellar lesion. The surgical specimen consisted of some slightly firm, brownish, irregular fragments of tissue, weighing $10 \mathrm{~g}$, and the largest one measuring $2 \times 1.5 \times 1 \mathrm{~cm}$. At microscopy, the process corresponded to a primary central nervous system (CNS) neoplasm with glial differentiation (Figure 2), showing hypercellular areas, moderate to severe cellular atypia, high mitotic index, areas of necrosis (Figure 3) and foci of marked microvascular proliferation. The neoplastic cells exhibited strong immunoexpression for glial fibrillary acidic protein (GFAP) (Figure 4), vimentin, S-100 protein, and a high proliferative index assessed by Ki-67 (MIB-1) immunoexpression. The set of

First submission on 07/12/12; last submission on 03/02/13; accepted for publication on 05/02/13; published on 20/04/13

1. Pathologist; post-doctorate in Pathologic Anatomy; professor at Universidade Luterana do Brasil (ULBRA)

2. Pathologist at Santa Casa de Porto Alegre; master's degree in Pathology by Universidade Federal de Ciências da Saúde de Porto Alegre (UFCSPA).

3. Medical graduate student at ULBRA. 
morphological findings were consistent with GBM (grade IV tumor). The patient was referred to radiotherapy, with slight signs of tumor regression on MRI scan after a 60-day clinical follow-up.

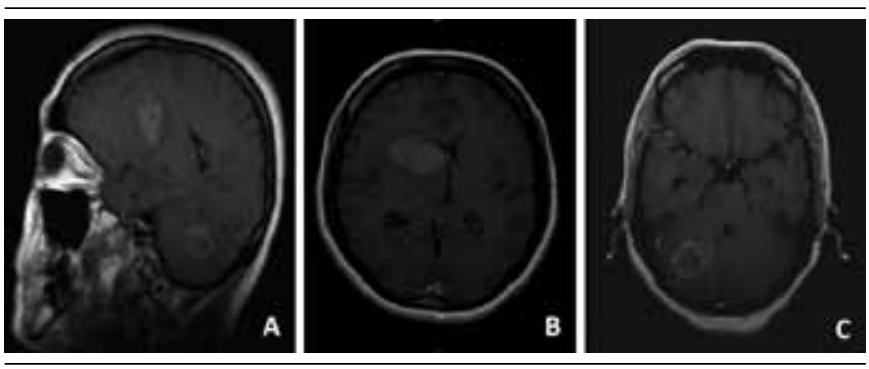

FIGURE 1 - MRI scans (A, B and C) showing two expansive bulky lesions arising in the thalamus (B) and cerebellar hemisphere, to the right, with an irregular ring contrast enbancement (C)

MRI: magnetic resonance imaging.

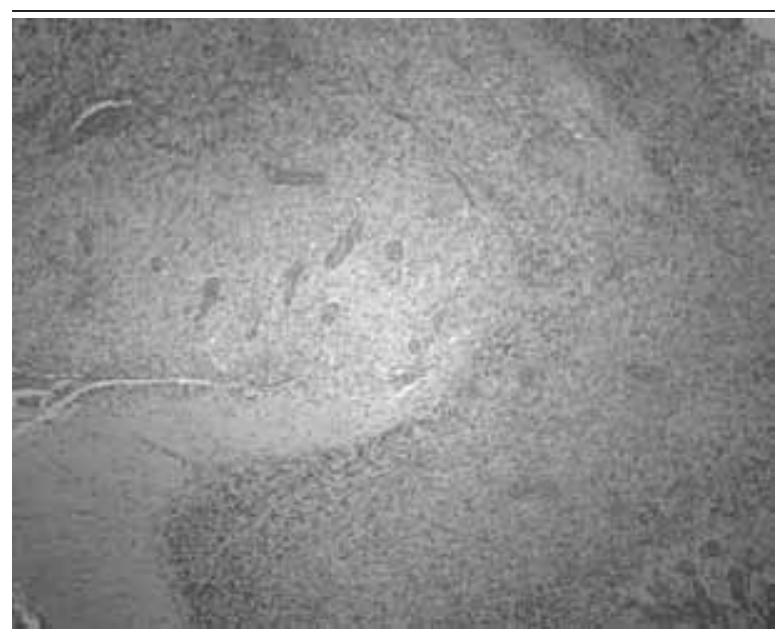

FIGURE 2 - Cerebellar parenchyma exbibiting a high grade glial neoplasm, with severe cellular atypia, microvascular proliferation and hypercellularity. HE, 40× HE: hematoxylin and eosin.

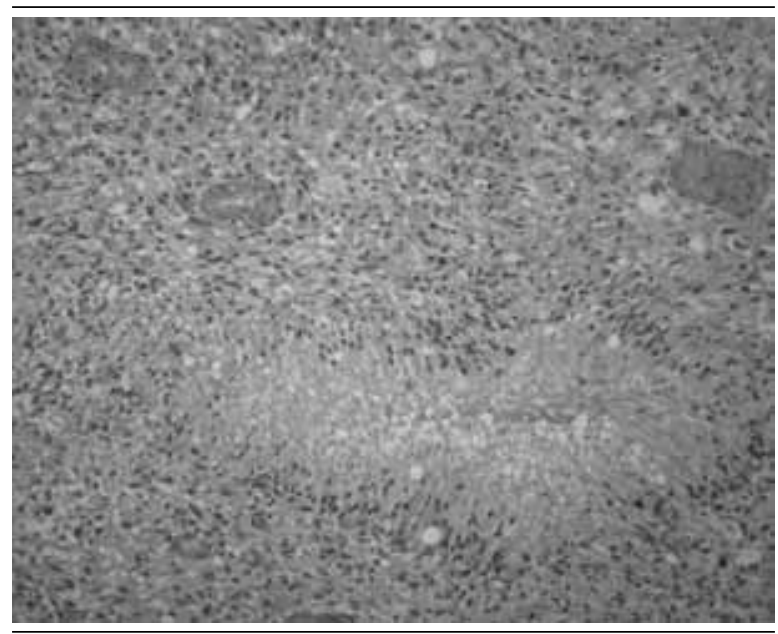

FIGURE 3 - A classic pattern of GBM: palisading around zones of necrosis. HE, 100×

GBM: glioblastoma; HE: hematoxylin and eosin.

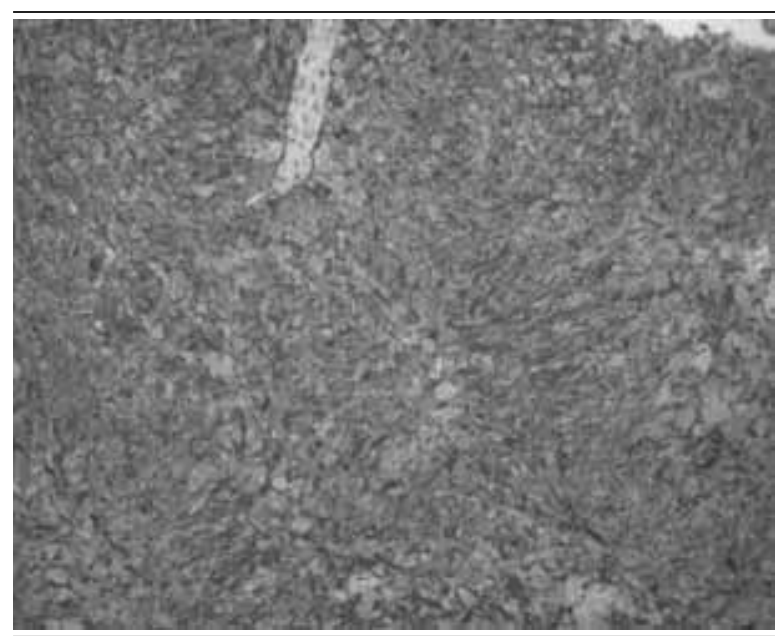

FIGURE 4 - GBM showing positive immunoexpression for GFAP, streptavidinbiotin, $100 \times$

GBM: glioblastoma; GFAP: glial fibrillary acidic protein.

\section{DISCUSSION}

MGBM are uncommon lesions of the CNS. Based on autopsy studies, the incidence of MGBM is approximately $2.5 \%-5 \%$, and they are predominantly found in the cerebral hemispheres of adults. In rare cases, children have been affected or the lesions have been located in infratentorial topography. The incidence of GBM arising in the cerebellum and thalamus is $0.24 \%$ and $4.5 \%$, respectively. In adults, the most common infratentorial tumors correspond to metastases, meningiomas and schwannomas. In children, medulloblastoma is the most common histological type affecting the posterior fossa. The clinical history of primary GBM affecting the cerebellum and/or the thalamus is usually brief, and symptoms/ signs of raised intracranial pressure are common. Thalamic lesions are also associated with the presence of contralateral paresis. Real MGBM are most likely polyclonal if they occur in infra and supratentorial topography $(2,3,7-11,13,14,23,26)$.

The diagnosis of MGBM can only be definitively established by careful sectioning and histopathological examination of intervening brain parenchyma between discrete tumor foci in order to ensure these tissues do not contain microscopic evidence of direct tumor extension $^{(4,5,24,25)}$. Batzdorf and Malamud reviewed 209 autopsyproved cases of GBM and found more than one focus of tumor in 58 cases $(27.8 \%)^{(5)}$. Salvati et al. reported a clinical series of seven cases of multicentric gliomas, including three suprainfratentorial tumors ${ }^{(25)}$. Barnard and Geddes evaluated 241 gliomas (astrocytomas, oligodendrogliomas, GBM, and subependymal giant cells astrocytomas) in post mortem specimens, and 23 cases (9.5\%) corresponded to true multicentric gliomas. In this series, after excluding cases in which there was concomitant disease (neurofibromatosis, tuberose sclerosis, or multiple sclerosis), 18 cases (7.5\%) of multicentric tumor remained. Among these 18 cases, nine specimens (50\%) proved to be MGBM, and the thalamus and cerebellum corresponded to the affected site in 3 different specimens 
for each one. No case involving the cerebellum and thalamus synchronously was identified ${ }^{(4)}$. Russell and Rubinstein described that the proportion of cases in which multifocal growth can be determined is a function of the extent to which the brain is sampled. The authors established that the distinctive features of true multicentric gliomas are mainly the absence of gross or microscopic connections and absence of seeding along easily accessible routes like the cerebrospinal fluid pathways or the median commissures ${ }^{(24)}$.

On CT or MRI scans, MGBM can mimic metastatic lesions and particularly abscesses. At macroscopy, GBM are poorly delineated single lesions, with central areas of necrosis and a gray peripheral zone. When large and superficial in location, GBM often expands a gyrus and reaches the surface as a hypervascular mass. The classical histopathological features include hypercellularity, nuclear atypia, cellular pleomorphism, areas of necrosis and microvascular proliferation ${ }^{(10,14,16,18,24)}$. In the present report, the two expansive bulky lesions were considered GBM due to its similar appearance and no obvious linkage between both tumors on CT/MRI scans. The thalamic tumor was not surgically removed owing to its inaccessibility. The most common tumors that metastasize to brain are originated from lung, breast, skin (malignant melanoma), kidney, and gastrointestinal tract. In patients with prior history of systemic neoplasia, the hypothesis of metastatic lesion has to be considered when a CNS tumor has been identified. The classic radiologic features of metastases include a spherical, contrast-enhancing lesion, sometimes with dark, necrotic centers, and perilesional areas of edema. The vast majority are situated in gray matter, typically near the gray-white junction. Metastatic adenocarcinomas are usually hypointense and dark on T2-weighted images. The brain stem is only rarely involved with metastatic processes. A pyogenic brain abscess is a localized focus of parenchymal suppuration that is originally bacterial, with only rare exception. In contrast-enhanced images, brain abscesses show a capsule that is thinner and more uniform than the irregular ring of enhanced GBM. In addition, the capsule of an abscess is dark on T2-weighted images, in accord with its collagen content. The cellular ring of GBM is usually white. A broad perilesional region of cerebral edema reflects the suppurative nature of the abscess ${ }^{(8,9,16-19,27-29)}$.

The median survival associated with cases of GBM is less than twelve months. The outcome of GBM depends chiefly upon the stage at which it is diagnosed, the site of the tumor and patient's age. In general, MGBM is associated with worse survival rates in comparison with solitary GBM. Surgical excision, radiotherapy and chemotherapy may increase the quality of life for the patient. Patients over the age of 65 have a particularly poor prognosis. GBM deeply seated in the thalamus, basal ganglia and posterior fossa also have a poor prognosis, since they are inaccessible to surgical excision. Whereas surgery regarding multicentric tumors is not ideal, the establishment of histopathological diagnosis is of paramount importance, insofar as treatment of GBM may differ considerably from that of multiple metastases ${ }^{(1,4,7,9-12,14,21)}$. The Table shows some cases of MGBM found in the international literature and comparable to the present report.

Herein, the authors present a single case of GBM due to its multicentricity and topography. MGBM compromising infra and supratentorial regions simultaneously in an adult patient is an uncommon finding. Despite a limited clinical follow-up of 60 days, and discrete signs of tumor regression, a poor prognosis is expected in this case.

TABLE - Summary of some published cases of multicentric glioblastoma confirmed by histopathological examination

\begin{tabular}{|c|c|c|c|c|}
\hline Authors & Age/gender & Topography & Treatment modality & Outcome \\
\hline Benveniste $^{(6)}$ & $65 / \mathrm{M}$ & Right hemisphere of the brain & $\begin{array}{l}\text { Biopsy + radiotherapy } \\
+ \text { chemotherapy }\end{array}$ & Unavailable \\
\hline Gasco & $67 / \mathrm{M}$ & Brain lobes & Total tumor removal & Unavailable \\
\hline Inoue $e^{(15)}$ & $33 / \mathrm{F}$ & $\begin{array}{l}\text { Cerebellum (vermis and } \\
\text { hemisphere) and internal capsule }\end{array}$ & $\begin{array}{l}\text { Subtotal removal of the vermis lesion }+ \\
\text { gamma knife irradiation }+ \text { chemotherapy }\end{array}$ & $\begin{array}{l}\text { Died within } \\
\text { eight months }\end{array}$ \\
\hline Jawahar ${ }^{(17)}$ & $73 / \mathrm{F}$ & $\begin{array}{l}\text { Left temporoparietal region and } \\
\text { right frontal lobe }\end{array}$ & $\begin{array}{l}\text { Stereotactic radiosurgery initially, and } \\
\text { afterwards the patient refused treatment }\end{array}$ & Unavailable \\
\hline Kieffer $^{(19)}$ & 62/M & $\begin{array}{l}\text { Right occipital lobe, right parietal } \\
\text { lobe and left frontal lobe }\end{array}$ & Biopsy & $\begin{array}{l}\text { Died within } \\
\text { eight days }\end{array}$ \\
\hline Kudo ${ }^{(20)}$ & 74/M & Cerebellum and Brain & $\begin{array}{l}\text { External decompression }+ \\
\text { ventriculoperitoneal shunt }\end{array}$ & Died within 2 months \\
\hline
\end{tabular}


TABLE - Summary of some published cases of multicentric glioblastoma confirmed by histopathological examination

\begin{tabular}{lcccc}
\hline Authors & Age/gender & Topography & Treatment modality & Outcome \\
\hline Miliaras $^{(22)}$ & $63 / \mathrm{M}$ & $\begin{array}{c}\text { Left frontoparietal region and } \\
\text { Right frontoparietal region }\end{array}$ & $\begin{array}{c}\text { Near total tumor removal (left lesion) }+ \\
\text { biopsy (right lesion) }\end{array}$ & Died within 10 months \\
Turola $^{(27)}$ & $43 / \mathrm{F}$ & Bilateral frontal lesion & Near total tumor removal & Unavailable \\
Present case & $61 / \mathrm{F}$ & Cerebellum and thalamus & $\begin{array}{c}\text { Total tumor removal (cerebellum) }+ \\
\text { radiotherapy }\end{array}$ & $\begin{array}{c}\text { Slight signs of tumor } \\
\text { regression after two months }\end{array}$ \\
\hline
\end{tabular}

M: male; F: female.

\section{RESUMO}

Glioblastomas multicêntricos (GBMM) originados em regiões infra/supratentoriais são lesões incomuns. Os autores relatam um caso de GBMM em paciente do sexo feminino, 61 anos de idade, que apresenta quadro súbito de hemiplegia esquerda. O exame de ressonância magnética (RM) mostrou duas lesões expansivas volumosas, com forte impregnação pelo contraste no cerebelo e no tálamo. Apaciente foi submetida à ressecção da lesão cerebelar. À microscopia, foi identificada uma neoplasia glial de alto grau exibindo alto indice mitótico, áreas de necrose e proliferação microvascular. As células neoplásicas revelaram imunoexpressão positiva para proteína glial acídica (GFAP). O conjunto das alterações morfológicas foi consistente com glioblastoma. A paciente foi encaminhada para radioterapia, com sinais discretos de regressão tumoral após acompanhamento clinico de 60 dias.

Unitermos: glioblastoma; neoplasias do sistema nervoso central; patologia; neoplasias encefálicas; cerebelo; tálamo.

\section{REFERENCES}

1. ALBRIGHT, A. L. Feasibility and advisability of resections of thalamic tumors in pediatric patients.J Neurosurg (Pediatrics 5), v. 100, p. 468-72, 2004.

2. ARCOS, A. et al. Multicentric glioblastoma multiforme. Report of 3 cases, clinical and pathological study and literature review. Neurocirugia (Astur), v. 23, p. 211-5, 2012.

3. BARA, P. N. et al. Glioblastoma cerebeloso. Caso clínico. Oncologia, v. 29, n. 3, p. 129-33, 2006

4. BARNARD, R. 0., GEDDES, J. F. The incidence of multifocal cerebral gliomas. A histologic study of large hemispheres sections. Cancer, v. 60 , p. 1519-31, 1987.

5. BATZDORF, U., MALAMID, U. The problem of multicentric gliomas. J Neurosurg, v. 20, p. 122-36, 1963.

6. BENVENISTE, R. J. et al. Multifocal glioblastoma multiforme with synchronous spontaneous hemorrhage: case report. J Neurooncol, v. 89, n. 1, p. 55-8, 2008.

7. BOZIC, B. et al. Cerebellar glioblastoma in the elderly - case report. Acta Clin Croat, v. 48, n. 2, p. 175-8, 2009.

8. COLOSIMO, C. et al. Neuroimaging of thalamic tumors in children. Child's Nerv Syst, v. 18, p. 426-39, 2002.

9. FERNANDEZ, C. et al. Thalamic gliomas in children: an extensive clinical, neuroradiological and pathological study of 14 cases. Child's Nerv Syst, v. 22, p. 1603-10, 2006.
10. GASCO, J. et al. Multifocal epithelioid glioblastoma mimicking cerebral metastasis: case report. Neurocirugia (Astur), v. 20, n. 6, p. 550-4, 2009.

11. GRAHOVAC, G. et al. Cerebellar glioblastomas: pathophysiology, clinical presentation and management. Acta Neurochir, v. 151, p. 653-75, 2009.

12. GOPALAKRISHNAN, C. V. et al. A retrospective study of primary cerebellar glioblastoma multiforme in adults. J Clin Neurosci, v. 19, n 12, p. 1684-8, 2012. 13. HERNANDEZ-GONZALES, G. et al. Long term survival in cerebellar glioblastoma multiforme. Case report. J Neurosurg Sci, v. 56, n. 4, p. 379-81, 2012.

14. HOU, L. C. et al. Congenital glioblastoma multiforme: case report and review of the literature. Pediatr Neurosurg, v. 44, p. 304-12, 2008.

15. INOUE, T. et al. Glioblastoma multiforme developing separately from the initial lesion 9 years after successful treatment for gliomatosis cerebri: a case report. No Shinkei Geka, v. 36, n. 8, p. 709-15, 2008.

16. IRONSIDE, J. W. Glioblastoma. In: IRONSIDE, J. W.; MOSS, T. H.; LOUIS, D. N.; LOWE, J. S.; WELLER, R. O. Diagnostic pathology of the nervous system tumors. New York: Churchill Livingstone, 2002, p. 88-99.

17. JAWAHAR, A. et al. Multicentric glioblastoma multiforme determined by positron emission tomography: a case report. Clin Neurol Neurosurg, v. 106, n. 1, p. 38-40, 2003.

18. KALINA, P. Pediatric cerebellar hemorrhagic glioblastoma multiforme. Open Neuroimag J, v. 6, p. 13-5, 2012.

19. KIEFFER, S. A. et al. Multifocal glioblastoma: diagnostic implications. Radiology, v. 143, p. 709-10, 1982. 
20. KUDO, H. et al. Multicentric glioblastoma multiforme occurring in the supra - and the infratentorial regions - case report. Neurol Med Chir (Tokyo), v. 30, n. 5, p. 334-8, 1990.

21. KUMAR, R.et al. Thalamic glioblastoma with cerebrospinal fluid dissemination in the peritoneal cavity. Pediatr Neurosurg, v. 31, n. 5, p. 242-5-1999.

22. MILIARAS, G. et al. Multifocal glioblastoma with remote cutaneous metastasis: a case report and review of the literature. Cent Eur Neurosurg, v. 9, n. 1, p. 39-42, 2009.

23. RANGER, A. et al. Pediatric thalamic glioblastoma associated with Ollier disease (multiple enchondromatosis): a rare case of concurrence. J Neurosurg Pediatrics, v. 4, p. 363-7, 2009.

24. RUSSEL, D. S. Glioblastoma. In: RUSSEL, D. S.; RUBINSTEIN, L. J. Pathology of tumours of the nervous system. 4. ed. Baltimore: Williams \& Wilkins, 1977, p. 240-1.
25. SALVATI, M. et al. Multicentric gliomas. Report of seven cases. Tumori, v. 77, p. 518-22, 1991.

26. STARK, A. M. et al. Glioblastoma of the cerebellum and brainstem.J Clin Neurosci, v. 17, n. 10, p. 1248-51, 2010.

27. TUROLA, M. C. et al. A rare case of multicentric synchronous bi-frontal glioma in a young female. Diagnostic and therapeutic problems: a case report. Cases Journal, v. 2, n. 1, p. 81, 2009.

28. UTSUKI, S. et al. Adult cerebellar glioblastoma cases have different characteristics from supratentorial glioblastoma. Brain Tumor Pathol, v. 29, p. $87-95,2012$

29. ZITO, J. L. et al. Glioblastoma of the cerebellum: computed tomographic and pathologic considerations. Surg Neurol, v. 19, p. 373-8, 1983.

\section{MAILING ADDRESS}

\section{Eduardo Cambruzzi}

Hospital Conceição de Porto Alegre; Av. Francisco Trein, 596,2º andar; Laboratório de Patologia; Cristo Redentor; CEP: 91350-200; Porto Alegre-RS, Brazil; Tel.: (51) 3357-2164; e-mail: dudacambruzzi@yahoo.com.br. 